Journal of Social Sciences 8 (2): 135-142, 2012

ISSN 1549-3652

(C) 2012 Science Publications

\title{
Learning Trajectories of Primary Student Teachers; a Cross-Cultural Comparison
}

\author{
Paul Gardner and Chris Rix \\ University of Bedfordshire, Polhill Avenue, Bedford, MK41 9EA, England
}

\begin{abstract}
Life history methodology was used to compare the life and educational trajectories of six primary student teachers in England with their counterparts at a Malawian Teacher Training College. A semi structured interview schedule was used to elicit the students' childhood memories including experiences of school, significant people in their lives, interactions with their teachers and influential factors in deciding to enter teaching. Students were also asked to expand their philosophy and purpose of education, to consider their immediate needs as newly qualified classroom practitioners and predict their career trajectory over a 20 year period. The cross-cultural analysis reveals causal biographical and socio-cultural factors combining to influence students' intentions to pursue teaching as a career. Teacher identity and notions of educational purpose revealed altruistic desires to teach, influenced by significant others in students' personal lives; educational narratives and the socio- political contexts of the respective societies. Choices made by the English students reflected the individualistic nature of British society whereas their Malawian counterparts were driven by a desire to improve children's education as a means of improving their country. In all cases the English students saw themselves remaining in primary education, in comparison all the Malawi students saw this as a stepping stone to a higher status role. This reflects the perceived low status that primary teaching has in Malawi and suggests that to improve education in Malawi a major priority should be to raise the status of primary teachers.
\end{abstract}

Key words: Continuing Professional Development (CPD), General Certificate of Secondary Education (GCSE), Junior Certificate Examination (JCE), Initial Teacher Education (ITE), life-history methodology, Malawi School Certificate Examination (MCSE)

\section{INTRODUCTION}

The research was embedded in a Continuing Professional Development (CPD) project between the Primary Education Department at the University of Bedfordshire, England and St. Joseph's Teacher Training College in the rural district of Dedza, Malawi. The three year DelPHE project, funded by the British Council, involved a collaborative team of academics from both institutions, who delivered CPD to 90 primary teacher practitioners working in schools in the districts of Dedza and Ntcheu. The team from England also included a group of six female primary student teachers. During a preliminary visit by the English academics to the region in September 2010, it was noted that the life experiences of female Malawian primary student teachers appeared distinctly different from those of their English counterparts. In addition, an informal comparison of modes of teacher training and primary classroom practice suggested significant differences could also be found in the education of teachers in England and Malawi. These observations raised questions about the life and education trajectories of primary student teachers in the two countries.

Osborn et al. (2003) draw on a substantial body of research to suggest teachers' identities and perceived professional responsibilities are constructed out of the interplay of the national culture and educational traditions in which they are situated. They add that students' individual 'learning biographies' are influenced by such factors as:

- Teachers' understandings and professional priorities

- Classroom ethos

- Institutional practices

- National educational policy priorities (Osborn et al., 2003)

Akyeampong and Stephens (2002) suggest that what teachers do in classrooms is influenced more by

Corresponding Author: Paul Gardner, University of Bedfordshire, Polhill Avenue, Bedford, MK41 9EA, England 
their '...socio-historical past, beliefs and values,' than it is by learning on teacher education programmes. Furthermore, they add that personal schemas of teacher behaviour are formed by means of the myriad interactions with teachers during schooling, which may be at variance with dominant discourse of what teaching is. These findings suggest that student teachers are simultaneously positioned both as learners and emergent professional teachers and are therefore, subject to the duality of dominant national cultural discourses and their own personal biographical 'footprints'.

Our comparative investigation set out to identify commonalities and divergences in students' lives and educational experiences. In addition, motives for choosing teaching as a career were identified. The socio-cultural frame of reference within which this study is situated can be exemplified in Fig. 1 which illustrates the 'nested' influence of socio-cultural and socio-political discourses on teachers, pedagogy and the identities of learners. The model is situated in a synthesis of Bronfenbrenner's bio-ecological systems theory (Bronfenbrenner, 1979) and Gramsci's theory of cultural hegemony (Gramsci, 1971).

In our socio-cultural model we posit that sociocultural and political discourses cascade through institutional discourses to teacher identity and classroom practice, which in turn frame pupil identity, along with the influence of family. The students in our study were once pupils whose identities, as pupils, become part of their trajectory into teaching. Hence, the biography of the student teacher is influenced by the biography of significant others (Stanley, 1992), namely previous teachers and influential members of family.

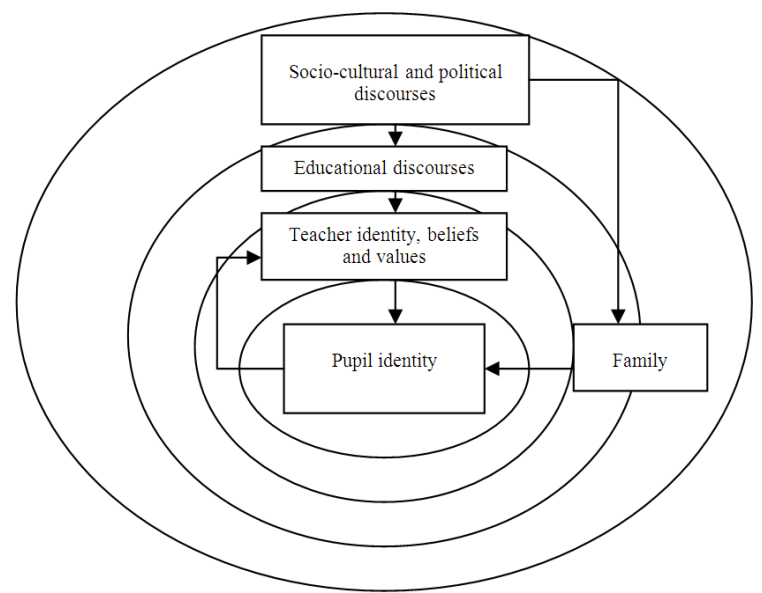

Fig. 1: Nested' socio-cultural model
However, these micro-influences reside within broader macro-influences of the dominant socioolitical discourse which shapes the relationship of the individual to the state and its socio-political ethos.

\section{MATERIALS AND METHODS}

The specific foci of this investigation were located around questions to with such things as: childhood memories; significant people in the lives of students; experiences of school and significant interactions with teachers; the age at which they began thinking about teaching as a career and the influential factors in their choice as well as their route into teaching. In addition, students were asked to expound their philosophy and purpose of education; to consider their immediate needs as newly qualified classroom practitioners and to predict their career trajectory over a 20 year period, following graduation.

By means of the use of life-history methodology the 'learning biographies and personal narratives' of the six female primary student teachers from England were elicited and compared with those of an equal number of female student teachers in Malawi. Bruner (2002) narratives are ways of learning and knowing about the world. Narrative, which re-emerged as a scholarly activity across disciplines in the second half of the Twentieth Century, synthesises an individual's cognitive and affective interpretations of their sociocultural world (Bresler, 2006; Squire et al., 2008) note this method of social research, which has its antecedents in humanism and the confluence of Russian Structuralism and French Post-structuralism, is concerned with analysing both individual identity and the social construction of lives. Stanley (1992) reminds us that 'memory is selective' and that biographies are not necessarily referential. Given that all the participants had difficulty remembering large parts of their childhoods, we would concur with this. Nevertheless, the fragmented narratives of students revealed the extent to which individual lives are infused with the lives of others and that all individual narratives are ideological accounts (Stanley 1992); that is the individual's autobiography is situated in the socioultural and political discourses of the era of lived experience. Not only are personal narratives socioultural 'documents' they also reveal the nature of the individual's identity. 'The storyteller does not tell the story, so much as s/he is told by it (Squire et al. 2008). If individual narrative reveals personal identity, which is itself situated in socio-cultural discourses, life history methodology reveals as much about society, as it does about the person. The particularity of individual narrative, which may be prone to a critique of subjectivity, becomes more reliable when patterns are 


\section{J. Social Sci., 8 (2): 135-142, 2012}

extrapolated across collective narratives in order to identify common causal social factors that transcend individual trajectories. In our analysis of students' lives, education and intended future trajectories, we identified and analysed these emerging patterns of experience to reveal the dialogic construction of these student teachers in their contrasting socio-cultural 'frames' of England and Malawi.

A semi-structured interview schedule was used to engage each student teacher in individual face to face naturalistic discussion with the researcher. Participants were self-selecting having volunteered to be involved in the research project. When, in Malawi, the English student teachers were paired with Malawian student teachers and used the same semi-structured schedule to elicit life history data from their counterparts. It is envisaged that by positioning the English students as researchers within a study in which they were initially the subjects will encourage critical self reflection and enable the English students to articulate significant points of similarity and difference between their own socially situated trajectories and those of their Malawian counterparts. Hence the investigation will evolve by means of multilayered, discursive and reflective practice.

The English student teachers: In addition to their shared gender, the student teachers in the English sample were in the third year of a four-year course, leading to a Bachelor of Education, Honours Degree (B.Ed.). Four of the six were local to the university. Of the remaining two, one student was originally from Finland and the second, although born in London, had made several trips to Jamaica as a child, where she attended school for a brief period. These two students were able to demonstrate some existing awareness of cross-cultural comparisons, as a result of their exposure to different education systems. Such comparisons can reveal 'ethnocentric assumptions' and illumine alternative perspectives (Osborn et al., 2003). Only two of the students had taken a conventional route into Initial Teacher Education (ITE) by commencing university on graduation from school at the age of 18 . Two of the others had begun alternative careers, before deciding to train to be teachers. The final two students began university courses, one to do a law degree and another to be a secondary PE teacher but both terminated in their first year, one because she disliked the routine of study and the other because she questioned her commitment to her chosen career. Both began paid employment. For one of these students the absence from study was short lived, after working as a teaching assistant for a year she returned to university to study primary education; for the other a successful career in retailing followed. The age profile of the sample ranged from 21-28, which is uncharacteristic of students in their year group, the majority of whom would be closer to a modal average of 21. Entry qualifications to teacher education in England require students to have a minimum of a $\mathrm{C}$ grade in English, Mathematics and Science at General Certificate of Secondary Education (GCSE), which are usually acquired at the age of 16 and a minimum point score of approximately 240, which is achieved by means of qualifications at Advanced Level or an equivalent approved course of study. Prospective students are also required to satisfy specific university selection requirements, involving tests in Mathematics and English, as well as group and individual interviews, conducted by academics in the Education Department. Students also have to demonstrate a commitment to teaching before being offered a university place.

The Malawi student teachers: The primary student teachers from Malawi were all nearing the end of the first year of their two year course at St Joseph's Teacher Training College (an all women college). One student had grown up in a village in the Dedza district, one was from a town in Southern Malawi, the rest were from villages in rural areas some distance from the college. All the students had passed the Malawi School Certificate Examination (MSCE) in Form 4 (the final year of secondary schooling) and, based on their results and a written application, were assigned to St Joseph's Teacher Training College by the government. The age profile of the sample ranged from 18-20 which is typical of students in their first year of teacher training in Malawi. Two of the students had considered other careers, before deciding on teaching, one in nursing and the other in the law.

The state of education in England and Malawi: The English education system has evolved from a humanist approach to learning which emphasises individualism, moral and spiritual values (Osborn et al 2003). Since the Education Reform Act of 1988, the state has levered increasing amounts of control over the curriculum and assessment practices, whilst devolving money and financial management to individual schools. However, these changes apply only to the state sector. Both England and Malawi have a two tier education system, separating autonomous private schools from the public sector. The two tier systems both reflect and reproduce inequalities of wealth, power and academic achievement. All of the students educated in England attended state schools. There is no private school sector in Finland and therefore the one Finnish student in this study had much in common with her English counterparts. However, Osborn et al (2003) note in 


\section{J. Social Sci., 8 (2): 135-142, 2012}

their comparative study of three European education systems, the Nordic countries are characterised by '. A strong tradition of communitarianism.' The extent to which the Finnish student's view of primary education was influenced by her society's dominant educational discourse was evident when she said, '..In primary school you learn how to be in society.' Later in the interview she returned to the cyclical nature of this correspondence when she stated.

That's what we do in Finland..Children help one another.. Collaboration is allowed.. I have not seen that happen in England... Finnish society is more cooperative than English society." (student I)

By positioning the English students as quasiresearchers, each one interviewing a Malawian counterpart, it is envisaged they will do what student I has done, perceive the nature of English culture, society and education through the lens of counter reflection, that is, learning about ourselves through what they learn about others. In their three-way comparative study Osborn et al (2003) concluded that English education is characterised by the twin themes of 'differentiation and individualism'.

During Kamuzu Banda's regime (1966-1994), most Malawians were denied basic education, 'only the rich, the best and the brightest were encouraged to attend secondary school' Stateuniversity.com, 2011a. In 1994 free primary education was introduced and although this has vastly improved access to education coping with the increase in numbers of pupils has created problems in assuring the quality of provision. The government has responded by re-evaluating the training of teachers and establishing a clear career path for primary teachers. This current '8-4-4' education system is comprised of 8 years of primary schooling (standard 1 to standard 8), 4 years of secondary school (Form 1-4) and usually 4 years of university education. Primary school begins at the age of six and is now compulsory and all pupils sit the Primary School Leaving Certificate exams at the end of standard 8. Those who pass are eligible to attend secondary schools which are all fee paying Southern and Eastern Africa Consortium for Monitoring Educational Quality, 2011. This means that many families cannot afford a secondary education for their children. In secondary school pupils sit a Junior Certificate Examination (JCE) in Form 2 and a Malawi School Certificate Examination (MCSE) in Form 4. MCSE results are used in the selection of candidates for training courses and employment. The Ministry of Education develops the curriculum delivered in Malawi schools and they also oversee teacher training. To become a primary teacher students now need an MCSE (type 2 teacher), or a JCE (type 3 teacher) and successfully complete a two year Teachers Certificate Stateuniversity.com 2011b. The first year of the Teachers Certificate is based in the Training College and the second year in one of the schools associated with the college.

A number of educational priorities were highlighted in the Ministry of Education, Science and Technology's statement concerning the National Education Sector Plan (NESP) 2008-2017. Malawi Ministry of Education, Science and Technology, 2008 This was devised to support the integration of all key players in the Malawi education sector and to respond to 'national and international aspirations during the given decade'. This statement sets out the views of the Government in relation to education sector goals and objectives and proposals as to how such goals and objectives will be achieved. The vision outlined in this document draws on the Malawi Growth and Development Strategy (MGDS) and sees the education sector as 'a catalyst for socio- economic development, industrial growth and instrument for empowering the poor, the weak and voiceless. Education enhances group solidarity, national consciousness and tolerance of diversity.' (Government of Malawi, 2006) Three thematic areas of intervention are identified within the NESP. These are to improve:

- Equitable access to education

- The quality and relevance of the curriculum

- Governance and management of the system

in all institutions from basic to higher education. A further major priority identified is to improve girls' enrolment and retention, particularly in secondary school, reflecting government policy to empower women in Malawi society.

\section{RESULTS AND DISCUSSION}

English student teachers: One outstanding characteristic of the English students was the stability of their lives from early childhood to the present time, which afforded them economic, emotional and psychological security. Significant childhood memories were located around anecdotes of family. These involved journeys to see grandparents, the birth of a sibling, family celebrations and leisure activities. The peer group featured to a far lesser extent than family. Childhood friends were almost absent or at best incidental in the stories of these students. When friends were mentioned it was in passing or they were referred to 


\section{J. Social Sci., 8 (2): 135-142, 2012}

as an amorphous mass associated with playing in large groups in the countryside. Family was at the centre of their childhood narratives and all students identified people in their nuclear family who were nurturing and supportive. In the main this was parents but not exclusively so. The one student who reported an absent father cited her mother and sisters as the ones who gave her guidance. Although this student reported a 'strict' family upbringing, the general tenor of family life was one of liberal paternalism:

- My dad was always at home to take me to clubs" (student I)

- Mum and dad were always there for me." (student $\mathrm{H}$ )

Parents were not overbearing and heavy with expectations of academic success. They rather put the onus on the child, 'to do their best.' Sometimes this laissez faire approach to parenting was accompanied by biographical analogy. One student reported how her father was in a 'successful job' but had begun his working life as a carpenter on a building site. The symbol of his low social status was the fact he could only afford jam in his sandwiches every day. She recalled nostalgically:

My dad has always taught me ... if you work hard at anything you will be successful." (student $\mathrm{H}$ )

The power of incidental advice was reported by another student who cited an occasion when a school friend had told her, "..even though you cannot do it, say you can." (student C). It was a refrain subsequently voiced every time she met a challenge in life. This student was also encouraged by her elder sister who had been to university and who had impressed upon her the '..Consequences of not studying enough'. These examples are indicative of a general finding that the individual life narratives of these students included the assimilated biographies of significant others. Although students were initially unable to identify any advantages they had had in life, reflections on the lives of their peers who had come from separated families caused them to reinterpret their own lives by means of contrastive biographies. With the exception of the student raised in Finland, there was recognition that family stability was a social marker between academic success and failure. This, combined with selfdetermination, especially at secondary school and excellent teachers, was perceived to be the driving force behind the academic success necessary to gain the prerequisite entry qualifications to teaching.

Outside the sphere of family, teachers were sometimes 'towering' figures in the lives of students as children and young people. In several instances specific teachers were cited as the inspiration behind the choice to become a teacher:

- Teachers really influenced me. In terms of wanting to be a teacher." (student $\mathrm{S}$ )

- My P.E. teacher... she was somebody I wanted to be." (student L)

- I had some amazing teachers at school." (student $\mathrm{Ch}$ )

It was not so much that students were generally influenced by teachers, as role models, or remembered them as effective practitioners, but rather that teachers had made learning enjoyable and were supportive.

- Teachers did a good job...I thought it would be nice to do the same for others." (student C)

What is evident from these statements is the affective impact both teachers and schools had on the lives of these students, as children. The positive social ambiance of school and the charisma of significant teachers appear to have influenced tendencies towards teaching as a future career for five of the English students. They traced first desires to be a teacher to early points in their lives, ranging from 9-13. Only one student chose teaching later in life, at the age of 24. Even those students who began careers outside teaching stated it had always been a desire.

The English students saw education both as a means of individual, as well as collective, improvement of children. The role of the teacher was seen as the facilitator who was there to 'make a difference' to children's lives.

- Without education there is nothing....if you cannot educate then I think the world would be a scary place. I think everyone has a right to a good education, irrespective of background." (student S)

- Education is the key.. If you are not educated ...you cannot achieve anything." (student C)

Implicitly these views are framed in altruistic desire, which can be traced back to students' own experiences of school. If the social dimension of school was under-stated by the students schooled in England, it was boldly stated by the student schooled in Finland:

In primary school you teach the skills, how to behave, how to learn and how to socialise with other people..the whole society is like a big school and school is like society... in primary school you learn how to be in society" (student I).

Her identity as a teacher and her future pedagogy, embedded in collaborative learning, was firmly located in her own experience of school, which was itself 


\section{J. Social Sci., 8 (2): 135-142, 2012}

indicative of the cooperative nature of wider Finnish society.

When discussing their reasons for entering the teaching profession the majority of English students had thought about being teachers at an early age. They wanted to duplicate their positive experiences of school and make a difference for individual pupils and children collectively. They also considered themselves as facilitators in supporting children's development as learners.

- Could see what a difference you can make with small groups of children especially children coming from a difficult background" (student S)

- I like the fact that I can help mould a child or children to be better individuals." (student C)

- Because I enjoyed being at school... made sense to go in to teaching. Teachers did a good job with me and nice to do the same." (student $\mathrm{Ch}$ )

The students all considered that their immediate needs, once qualified and in their first teaching post, would be a supportive environment working with members of staff who were approachable and able to provide advice.

- A good support system from other members of staff." (student $\mathrm{S}$ )

- Having support from somebody who can guide you, putting everything in to place." (student L)

- Having support of people working with to get general advice..." (student $\mathrm{Ch}$ )

- Support...I think...that constant reinforcement that you are doing it right..." (student $\mathrm{H}$ )

Their longer term aspirations involved promotion to various posts of responsibility but all still within the primary education sector. One student's long term ambition is to influence education policy.

- Moving towards being a team leader for a Key Stage. Maybe later a head teacher....Unless something drastic happens I see myself as staying in the teaching profession." (student $\mathrm{S}$ )

- I hope to remain in teaching...would like more responsibility perhaps a deputy head with responsibility but still teaching." (student L)

- I would like to think I will still be teaching in 20 years time....If the opportunity came along maybe become a head teacher but my main goal is to be a teacher." (student $\mathrm{Ch}$ )

- I see myself as a deputy head or head teacher.... I would definitely like to influence policy in education." (student $\mathrm{H}$ )
Malawi student teachers: In contrast to the English students the family life of the Malawi students was generally less stable. One student was orphaned at the age of 2, both her parents dying of malaria. She then lived with her grandmother, but at a young age was responsible for supporting herself and her elderly grandparents. I worked growing different crops like tomatoes, beans maize. After that I was selling them to get money to help myself and my grandparents." (student Z)

However her grandmother was seen as being significant in the encouragement she gave.

My grandmother she was the one who kept encouraging me in working hard in school and at the church" (student Z)

Another student's parents often argued due to her father's drunken behaviour and they separated when she was five. They got back together but then both her parents died, her father when she was nine years old and her mother when she was aged thirteen. She was then reliant on her sisters to support her.

Other students did have more stable family lives but parents although supportive did not always encourage them to go in to the teaching profession.

My family loved me so much being the last born... My mum wanted me to be a teacher. My father did not like me to be a teacher because in Malawi teachers are not being respected as professionals." (student W)

What was significant for all the students was the provision of financial support to help them with their schooling and secondary school fees. When this was not available from parents, significant other family members provided financial support.

They (her mother and father) encouraged me in the educational activities and they provided me with the educational needs, for example when I need a bag, school shoes they bought it for me." (student Y)

My sister I said is an accountant so she, money help me with a lot of things"

In the case of student $\mathrm{Z}$, who was working to support herself, two years of her secondary schooling fees were provided by social welfare.

School fees changed...I went to social welfare and they paid for me from year 2-4" (student Z)

Unlike the English students, experiences with teachers in school were often seen as negative. Incidences of male teachers propositioning female students, use of abusive language and physical punishments were referred to. The students indicated how they reflected on these experiences and were inspired to be different and act as role models when they became teachers.

Male teachers were also using abusive language when advising us....they were unkind...... I want to be a good teacher to my learners..... I would help them (the pupils) if they are finding difficulties.... Help them 
patiently and give them proper advice not to embarrass them." (student W)

I had problems with mathematics, when you did not pass mathematics he (the mathematics teacher) gave you punishment that is why I was running away from school.... We should love them (the pupils) and know what their problem is because we have different problems coming in to school so we have to think very slowly so that learners should understand"

One student did refer to her primary teacher as inspirational and commented on the encouragement he gave to get an education and succeed in life.

I used to love my teacher he respected me.... he used to encourage us we had an education so that we can succeed in life." (student Y)

The Malawi students saw education as a way of bettering their country, providing good leaders and improving the quality of life, reflecting the current government's education priorities:

- To develop the standards of living for the learners and to socialise the learners" (student Z)

- Impart knowledge in learners for them to be good leaders in the future....If the country does not have good leaders it will continue to be poor...I want to impart knowledge to remove primitive life" (student W)

- To end ignorance because here in Malawi there is more ignorance... if the education is not better children are just getting married, dropping out of school, that means it is not good for our country." (student Y)

A further government priority that was reflected in the students' responses was the empowering of women:

- I want to empower a lot of girls...I want to inspire them to be educated." (student X)

- When considering their reasons for going in to teaching one key factor highlighted was to escape from poverty

- I was thinking I do not want to be a beggar in my whole life." (student Z)

- I go for teaching because that was the only profession for which I was qualified to do." (student W)

However the major reasons cited by the students were to act as role models, to help better their pupils' prospects and to improve the country.

- I could develop different lives of people so they could maybe depend on themselves." (student Z)
- You know in rural areas when they (girls) see a person like me saying I am a teacher they are inspired a lot" (student X)

- Because teachers act as role models...... to end ignorance because here in Malawi there is more ignorance" (student Y)

When considering their immediate needs, once qualified and starting their teaching careers, the Malawi students focused on issues relating to physical infrastructure and inadequate teaching and learning materials, reflecting the inadequate funding and management available in primary schools:

- I may need good accommodation... more resources in my school where I will be teaching" (student Y)

- Maybe somewhere where you can live....I might need some good building and maybe a mattress." (student X)

- Just resources in Malawi we have poor resources.... Our salaries... sometimes we receive our salaries very late..." (student W)

The Malawi students' longer term aspirations highlighted the relatively low status a primary teacher has in Malawi. In contrast with the English students, not one saw themselves as remaining in a primary teaching environment. They all saw being a primary teacher as a stepping stone to what they considered to be a higher status role; a secondary teacher, a lecturer or in one case a lawyer:

- My goal is I want to be a secondary teacher....I am also going to apply to be a lecturer" (student $\mathrm{Y}$ )

- I want to be a teacher but my vision is to be a lecturer" (student X)

- I promise that I will never die a primary teacher I will carry on from there up till I reach a college teacher." (student Z)

- I want to be a lawyer one day" (student W)

\section{CONCLUSION}

By means of a comparative study of English and Malawian primary student teachers, multiple influences for choosing teaching as a career were identified in common to both groups. These included: personal experiences of school; teacher- pupil relationships; family background and supportive significant otherseither parents or other family members; self determination and a desire to help children. Education was seen as a 
means of personal advancement and social progress. However, these micro-influences were framed within the different socio-political discourses of the respective societies. Whereas choices made by English students reflected the individualistic nature of British society, their Malawian counterparts were driven by a desire to improve children's education as a means of improving their country, reflecting the political priorities of the present Malawian Government.

\section{REFERENCES}

Akyeampong, K. and D. Stephens, 2002. Exploring the backgrounds and shaping of beginning student teachers in Ghana: Toward greater contextualisation of teacher education. Int. J. Educ. Dev., 22: 216-274. DOI: 10.1016/S07380593(01)00064-5

Bronfenbrenner, U., 1979. The Ecology of Human Development: Experiments by Nature and Design. 9th Edn., Harvard University Press, Cambridge, MA: ISBN: 10: 0674224574, 330.
Bresler, L., 2006. Embodied Narrative Inquiry: A Methodology of Connection. Res. Stud. Music Educ. 27: 21-43. DOI: $10.1177 / 1321103 X 060270010201$

Bruner, J. 2002. Narratives of human plight: A conversation with Jerome Bruner.

Gramsci, A., 1971. Selections from the prison notebooks. International Publishers, New York.

Osborn, M., P. Broadfoot, E. Mcness, C. Planel and B. Ravn et al., 2003. A World of Difference?: Comparing Learners Across Europe. 1st Edn., Open University Press, Maidenhead, ISBN: 10: 033521102X, 282.

Squire, C., M. Andrews and M. Tsamboukou, 2008. Introduction: What is Narrative Research. In: Doing Narrative Research, Andrews, M., C. Squire and M. Tamboukou, (Eds.). SAGE Publications Ltd, ISBN-10: 1412911974, pp: 1-21.

Stanley, L., 1992. The auto/biographical I: the theory and practice of feminist auto/biography. 1st Edn., Manchester University Press, Manchester, ISBN10: 0719029805, pp: 289. 